NBER WORKING PAPER SERIES

\title{
DO GLOBAL PANDEMICS MATTER FOR STOCK PRICES? LESSONS FROM THE 1918 SPANISH FLU
}

\author{
Marco Del Angel \\ Caroline Fohlin \\ Marc D. Weidenmier \\ Working Paper 28356 \\ http://www.nber.org/papers/w28356 \\ NATIONAL BUREAU OF ECONOMIC RESEARCH \\ 1050 Massachusetts Avenue \\ Cambridge, MA 02138 \\ January 2021
}

We are grateful to Juan Rubio, Dennis Aigner, Asaf Bernstein, Eric Hughson, and Gustavo Cortes for helpful comments. We thank Zhikun $\mathrm{Lu}$ for indefatigable research assistance and Joanna $\mathrm{Bu}$, Chenxi $\mathrm{Li}$, and Jason Wang for meticulous error checking of the stock prices. Caroline Fohlin acknowledges financial support from the National Science Foundation. The views expressed herein are those of the authors and do not necessarily reflect the views of the National Bureau of Economic Research.

NBER working papers are circulated for discussion and comment purposes. They have not been peer-reviewed or been subject to the review by the NBER Board of Directors that accompanies official NBER publications.

(C) 2021 by Marco Del Angel, Caroline Fohlin, and Marc D. Weidenmier. All rights reserved. Short sections of text, not to exceed two paragraphs, may be quoted without explicit permission provided that full credit, including $(\odot$ notice, is given to the source. 
Do Global Pandemics Matter for Stock Prices? Lessons from the 1918 Spanish Flu

Marco Del Angel, Caroline Fohlin, and Marc D. Weidenmier

NBER Working Paper No. 28356

January 2021

JEL No. G1,I1,N2

\begin{abstract}
$\underline{\text { ABSTRACT }}$
We study the impact of the 1918 Spanish Flu on U.S. stock prices. We use the death rate to control for the impact of the global pandemic and war news reported in the New York Times to capture the positive effects of the end of World War I on stock prices. Using a new weekly hand collected NYSE stock price index, we show that there is a -.73 correlation between the aggregate stock market and the death rate. Furthermore, vector autoregressions demonstrate that the death rate can explain up to 24 percent of the forecast error variance in the aggregate stock index from September 1918 until the end of the pandemic in March 1920. We also find that the flu had a significant, but varied impact on nine NYSE sectors. The empirical analysis indicates that pandemics can matter big time for stock prices.
\end{abstract}

Marco Del Angel

California State University Los Angeles

5151 State University Drive

Los Angeles, CA 90032

mmarti29@calstatela.edu

Caroline Fohlin

Department of Economics

Emory University

Atlanta, GA 30303

cfohlin@emory.edu
Marc D. Weidenmier

Argyros School of Business and Economics

Chapman University

One University Drive

Orange, CA 92866

and NBER

weidenmi@chapman.edu 


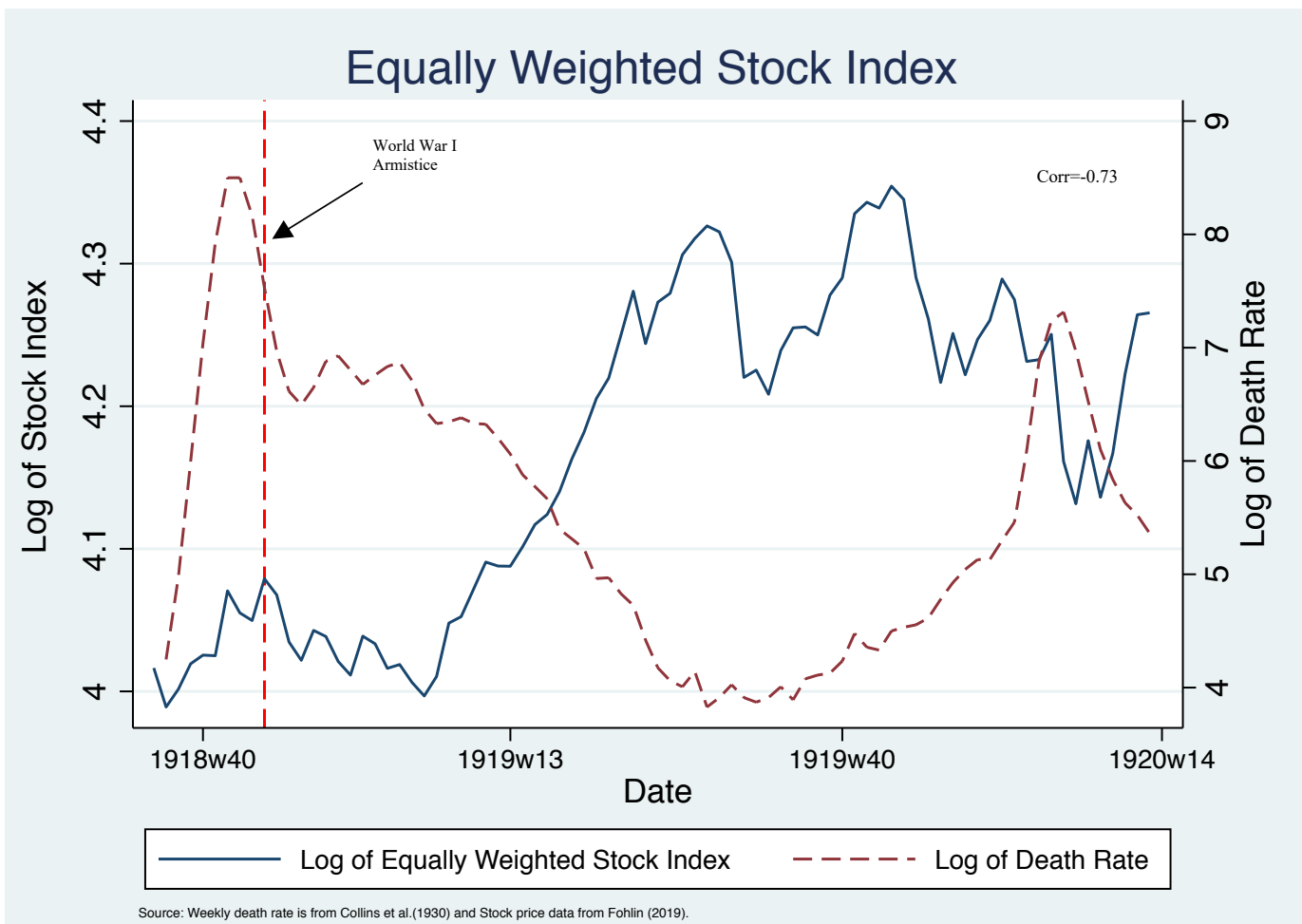

\section{Introduction}

We provide an historical perspective on the impact of a global pandemic on stock prices. The Spanish flu was the deadliest pandemic of the twentieth century. It killed approximately 2 percent of the global population and 675,000 Americans over a two-year period that covered four waves of the virus. We examine the effect of the 1918 Spanish Flu on the aggregate U.S. stock market given that the influenza was the last global pandemic that is similar in magnitude to the current coronavirus outbreak. Our study uses a new weekly, equally-weighted stock index of 149 firms constructed from stock prices taken from the New York Times. Simple descriptive statistics suggest that the pandemic may have mattered big time for stock prices given that the simple correlation coefficient between the log death rate and the log of the aggregate stock index is -.73 
from September 1918 to March 1920. The nine NYSE sectors in our sample also have correlation coefficients with the flu variable ranging from -.40 to -.76. ${ }^{1}$

We focus on the impact of the virus on the aggregate stock market as opposed to GDP because macroeconomic data are often only available at the annual frequency for this time period and of questionable quality given that national income accounting was developed in the postWorld War II period. Furthermore, the aggregate stock market has been shown to forecast future economic activity (Fama 1990; Schwert, 1990). Our new weekly U.S. stock index provides high frequency identification and a window into the effects of the influenza on the aggregate stock market as well as different stock market sectors. ${ }^{2}$

An empirical analysis of the Spanish flu is potentially complicated by the fact that the grip was concurrent with the end of World War I. It is likely that the influenza had a negative impact on stock prices while asset prices increased in value with good war news and an end to the World War. To separately identify the two factors, we estimate vector autoregressions to measure the dynamic impact of the Spanish flu and World War I on U.S. stock prices. We use the death rate to control for the impact of the grip on stock prices and war news reported in the New York Times to capture the effect of World War I on asset prices. We employ vector autoregressions for the empirical analysis since we have a small number of stock sectors (9), and a much larger number of weeks (81 weeks) in the data sample.

The empirical analysis demonstrates that the Spanish flu had a large impact on the stock market. Specifically, we find that the Spanish flu can explain 24 percent of the forecast error

\footnotetext{
${ }^{1}$ In the Appendix we plot the association between sectoral stock market indices and death rate.

${ }^{2}$ Barro et al. (2020) examine the impact of the Spanish flu on economic activity in a cross-section of countries over time. They find that influenza reduced real stock prices in their panel analysis. Bodenhorn and Velde (2020) examine the impact of the Spanish flu on U.S. economic activity. Cortes and Verdickt (2020) examine the impact of the Spanish flu on the U.S. insurance industry.
} 
variance in the aggregate U.S. market from September 1918 until March 1920. Furthermore, we find that the pandemic had a significant, but varying impact across nine NYSE sectors. We also find that war news increased stock prices as the Allies marched to victory in the fall of 1918 . Overall, the analysis suggests that the 1918 Spanish flu had a large negative impact on U.S. stock prices and probably depressed the market for more than a year.

We begin the empirical analysis with a brief history of the pandemic in the United States. Then we provide a description of the data used in the study. This is followed by an empirical analysis of the 1918 Spanish flu using vector autoregressions. We then conclude the study with a discussion of the implication of the results for asset returns and pandemics.

\section{A Brief History of the 1918 Influenza Pandemic}

As the U.S. scaled up training and troop deployments in the last year of World War I, a novel influenza virus began spreading. Detected in Kansas in March of 1918, the new influenza spread through the Army training camp in Fort Riley, Kansas: Over 100 soldiers became ill in March and the number of flu cases increased five-fold within a week (CDC, 2018). The first public mention of the pandemic came in April 1918 with 18 cases and 3 deaths in Haskell, Kansas. The U.S. military grew to 4.7 million soldiers by April 1918, and dozens of camps across the U.S. trained tens of thousands of troops at a time creating ideal conditions for spreading the virus through the military. As the war continued, hundreds of thousands of soldiers traveled to Europe each month. The first wave of the influenza made little news in the U.S., and U.S. cases waned over the summer. Through the spring and summer of 1918 
newspapers published articles about the "grip" and "German sickness" - all focused on the spread of flu in Europe and often emphasized its negative impact on the enemy.

By September, the second wave arrived back in the US, appearing first in military bases in the Boston area. "By the end of September, more than 14,000 flu cases are reported at Camp Devens - equaling about one-quarter of the total camp, resulting in 757 deaths" (CDC, 2018). Again, the close quarters facilitated the spread of the virus among the troops, and the movements of troops continued to transport the virus back across the Atlantic to the U.S. The autumn 1918 wave brought far more infections, community spread, and high death rates. According to a "war department" analysis at the time, the pervasive outbreaks of flu among enlisted men cost the Army 8,743,102 work-days in 1918 alone (Byerly, 2010).

The flu struck and spread to different regions across the country, depending both on transportation patterns and on the mitigation measures different cities took. Some locales closed gathering places (movies, theaters, pubs, and some types of schools), required masks in public, and forced sickened individuals and whole families into quarantine. Some cities hosted mass war victory celebrations, which caused huge spikes in infections and deaths.

The third wave developed over the winter and spring of 1919. San Francisco recorded 1,800 new cases and 101 deaths in the first five days of January (CDC, 2018). Even President Wilson was stricken, collapsing at the Versailles conference in April 1919. Flu subsided over the summer of 1919 but more cases emerged over the subsequent winter, creating a fourth wave that continued into the early months of 1920 — clearly evident in the "death rate" shown in Figure 1. 


\section{Data}

The data come from the New York Stock Exchange (NYSE) database detailed in Fohlin (2019). The data used in this paper include transaction prices for all common stocks that traded on the NYSE every Friday from 1918 through 1920. The full dataset covers 1911-1925 and incorporates all data reported in the New York Times stock tables: The data include the full company names with details on type of security (preferred, rights, trust certificates), ex-dividend days, ex-rights days, and any other details; number of shares traded ("sales"); first and last transaction prices, as well as high and low transaction prices; and the quoted bid and ask prices prevailing at the close of the market. Our total market index is an equally-weighted average of 149 stocks that had no more than two weeks in which they did not trade. The sample covers the period September 1918 through March 1920 for a total of 81 weekly observations.

We employ weekly death rates from influenza and pneumonia for 35 cities in the United States. The data are taken from Collins et al. (1930). Our sample begins in September 1918, the first month for which there is weekly mortality data from the flu, and ends in March 1920 after the end of the fourth wave of the pandemic. War news is defined as the weekly number of newspaper stories (article, display ad, editorial article, front page and letter to editor) that mention terms related to World War I in the New York Times from September 1918 to March 1920. To construct this variable we searched the ProQuest Newspaper Archive for stories that contained the following keywords: i) "world war" or "Great War" or "European War", and ii) one of the following terms : "deaths" or "casualties" or "military conflict" or "invasion" or "blockade" or "killed in action" or "fatalities" or "killed in battle". 


\section{Empirical Analysis}

We begin the empirical analysis by looking at simple descriptive statistics for the variables used in the empirical analysis. Table 1 reports the mean and standard deviation for the aggregate stock market and control variables. The equally-weighted stock index has a mean value of 65.11 and a standard deviation of 7.26. The death rate variable has a mean of 581.37 and a standard deviation of 907.38. The flu variable has a large standard deviation which reflects the dramatic rise in deaths with the outbreak of the grip in August and September 1918. The log of the pandemic covariate has a -.73 percent correlation with the log of the aggregate stock index. The war news variable has a mean of 2.21 and a standard deviation of 1.53 .

Next, we estimate vector autoregressions (VARs) to analyze the dynamic effects of the Spanish flu on U.S. stock prices. We use VARs because our data sample has a small number of stock sectors (9) and a much longer time series of asset prices (81 weeks). The makeup of the data series strongly suggests time series methods as opposed to a panel analysis that relies primarily on the cross-section for identification. Formally, we estimate the following specification:

$$
Y_{t}=\mathbf{A}_{0}+\mathbf{A}_{1} Y_{t-1}+(\ldots)+\mathbf{A}_{P} Y_{t-P}+\varepsilon_{t}, \quad \varepsilon_{t} \sim N(0, \Sigma)
$$

where $Y_{t}$ is a vector of macroeconomic variables described below, $\mathbf{A}_{0}$ is a matrix of intercept coefficients, and $\mathbf{A}_{1}$ through $\mathbf{A}_{P}$ are matrices of coefficients relative to each lag of $Y$, ranging from 1 to $P$. To obtain causal relationships between the variables of the VAR, we estimate equation (1) and map the reduced-form shocks $\varepsilon_{t}$ into structural shocks applying a Cholesky decomposition of the variance-covariance matrix $\Sigma$. This procedure-known as recursive identification implies that the ordering of the variables matters for determining the dynamic relationships between the VAR variables. 
We specify a three-variable vector autoregression (VAR) that includes the log of the equally-weighted stock price index of NYSE firms (NYSE), a World War I news variable (NEWS), and the log of the death rate (DEATH). The sample covers the period from September 1918 until the end of March 1920. We select a lag length of 2 weeks based on the Akaike Information Criteria (AIC). The impulse responses show the impact of a one-standard deviation shock to the death rate and war news on stock prices along with 68 percent confidence intervals. We give the log of the equally-weighted index the first ordering since asset prices quickly respond to new information. War news is given the second ordering since World War I predates the outbreak of the Spanish flu. This means that the log of the death rate is given the third ordering. ${ }^{3}$ The impulse responses for the aggregate stock market are reported in Figure 2. A onestandard deviation shock to the death rate reduces the equally-weighted stock index. A shock to the war news variable also has a statistically significant effect on stock prices. As for the forecast error variance, we find that the death rate can explain 24 percent of the movements in stock prices after 16 weeks. On the other hand, the war news variable can only account for about 3.7 percent of the fluctuations in stock prices ${ }^{4}$. The significant, but small impact of the war news variable may be explained by the fact that World War I ended three months into our sample period. If flu data were available starting in 1918 , it is likely that war news would have a much larger impact on stock prices. Another possibility is that lags of the aggregate stock market index might also capture the positive effect of war news on asset prices.

\footnotetext{
${ }^{3}$ The empirical results are robust to giving death rate the second ordering in the Cholesky decomposition. Details are available from the authors by request.

${ }^{4}$ The results are robust if we restrict the sample to years 1918 and 1919. Death rate can explain 42 percent of the movements in stock prices after 16 weeks, while war news can explain 4 percent of the fluctuations in stock prices. Also, at $90 \%$ confidence level, death rate continues to have a robust and significant effect on stock prices, while war news has no effect.
} 
Overall, the empirical analysis demonstrates that the Spanish flu had a large and negative impact on the aggregate stock index. ${ }^{5}$

We follow-up the baseline analysis by examining the impact of the Spanish flu on nine sectors of the New York Stock Exchange. The nine sectors are automobile, consumer products, light manufacturing, mining and oil, other manufacturing, railroads, steel, trade and services, and utilities. We use the equally-weighted index to control for overall market conditions. Table 2 reports summary statistics for the nine NYSE sectors. The mean index value ranges from 33.84 for mining and oil sector to 111.19 for trade and services. The standard deviation ranges from 2.56 for mining and oil to 20.40 for automobiles. The log of the nine sector indices has a correlation coefficient ranging from -.40 to -.76 which indicates a strong statistical relationship between the pandemic and the aggregate stock index.

Figure 3a shows the impulse responses of a given sector to a one-standard deviation shock to the $\log$ of death rate. We give the $\log$ of the sector index the first ordering, followed by the $\log$ of the market index, war news, and the $\log$ of the death rate. ${ }^{6}$ Table 3 shows the forecast error variance for each of the nine sectors. Figure 3 a shows that the death rate significantly lowers the automobile index. The Spanish flu can explain 17.7 percent of the movements in the automobile index after 16 weeks. Second, the consumer products index presented in Figure 3a significantly falls in response to a one-standard deviation shock to the flu variable. The death rate can account for 23.3 percent of the movements in the consumer products index after 16 weeks.

With respect to light manufacturing, Figure 3a shows that the death rate significantly reduces the light manufacturing sector. The death rate can account for 13.9 percent of the movements in the

\footnotetext{
${ }^{5}$ We also looked at the impact of mitigation measures on stock prices. Mitigation measures included public gatherings bans and school closures across 39 cities. Although the mitigation measures were statistically significant, they explain less than one percent of the forecast error variance in stock prices

${ }^{6} \mathrm{Lag}$ lengths for the sector VARs were selected on the basis of the AIC criteria.
} 
light manufacturing sector index after 16 weeks. A shock to the death rate presented in Figure 3a significantly decreases mining and oil. The grip can explain 23 percent of the movements in the industrial index after 16 weeks. An increase in the death rate significantly reduces the other manufacturing sector in Figure 3b, explaining 19.1 percent of the movements in the sector after 16 weeks.

The railroad index also shown in Figure $3 \mathrm{~b}$ significantly falls in response to a onestandard deviation shock to the influenza variable. The flu can explain 5.7 percent of the fluctuations in the railroad sector. In addition, the steel sector presented in Figure $3 \mathrm{~b}$ declines following a shock to the death rate. The influenza variable can explain 13.4 percent of the movements in steel. A shock to the death rate significantly reduces the trade and service index. The death rate can account for 21.4 percent of the movements in the trade and service index after 16 weeks. Finally, the utility sector falls in response to a shock to the death rate. The flu variables explain 24.1 percent of the fluctuations in the utility sector.

With respect to the impact of war news on stock prices, Figures $4 \mathrm{a}$ and $4 \mathrm{~b}$ show that a one-standard deviation shock to war news has a statistically significant effect on four of the nine sector indices. A one-standard deviation shock to war news significantly increased consumer products, light manufacturing, steel, and trade and services. War news can explain 5.5, 3.7, 2.0, and 6.3 percent of the forecast error variance (FEVD) for the four sectors at a sixteen-week forecast horizon, respectively.

The rise in the U.S. stock market in 1918-1920 also reflects the return to a peacetime economy that was shifting from producing guns to butter. Trading activity on the NYSE, for example, grew rapidly at the end of World War I and the early 1920s. The number of actively traded common stocks increased from roughly 150 to 250 between 1918 and 1920. Meanwhile, 
volume (number of shares traded) rose from an average of 380 thousand shares in the 1911-14 period to nearly 870 thousand shares on average in the 1919-22 period. Dollar volume, in nominal terms, rose less dramatically, from an average of $\$ 37$ million per day in the early period to about $\$ 55.5$ million per day in the post-war period.

\section{Conclusion}

We examine the effect of the 1918 Spanish flu, a global pandemic, on U.S. stock prices. We estimate simple vector autoregressions to assess the impact of the influenza on firms that traded on NYSE using a new weekly stock price index collected from the New York Times as well as news articles to control for the impact of the end of World War I. Simple summary statistics show that there a -.73 correlation between the $\log$ of the death rate and the $\log$ of the aggregate stock index. Then we estimate vector autoregressions that demonstrate that the grip can explain up to 24 percent of the forecast error variance of the aggregate U.S. stock market after 16 weeks. We follow-up the aggregate analysis by examining the effect of the influenza on nine NYSE sectors. The analysis shows that the pandemic had a significant and negative impact on all nine sectoral indices. The empirical analysis demonstrates that the Spanish flu mattered big time for U.S stock prices from 1918-1920. 


\section{References}

Barro, R., Ursua, J., \& Weng, J. (2020). The Coronavirus and the Great Influenza Epidemic: Lessons from the "Spanish Flu" for the Coronavirus' Potential Effects on Mortality and Economic Activity. Washington: American Enterprise Institute.

Bodenhorn, Howard. (2020). "Business in a Time of Spanish Influenza.” NBER Working Paper No. 27495

Byerly, C. (2010) “The U.S. Military and the Influenza Pandemic of 1918-1919,” Public Health Rep. 125(Suppl 3): 82-91. https://www.ncbi.nlm.nih.gov/pmc/articles/PMC2862337/\#B4

CDC .(2018). website: https://www.cdc.gov/flu/pandemic-resources/1918commemoration/pandemic-timeline-1918.htm

Collins, Selwyn D., W. H. Frost, Mary Gover, and Edgar Sydenstricker. (1930). "Mortality from Influenza and Pneumonia in 50 Large Cities of the United States, 1910-1929." Public Health Reports, 1896-1970 45: 2277-2328.

Cortes, Gustavo and Gertjan Verdickt. (2020). "Did the 1918-19 Influenza Pandemic kill the U.S. Life Insurance Industry?” University of Florida Working Paper.

Fama, Eugene. (1990). "Stock Returns. Expected Returns, and Real Activity.” Journal of Finance 45: 1089-1108.

Fohlin, Caroline (2019) "The NYSE from the Great War to the Great Depression," Working Paper, Emory University.

Markel H, Lipman HB, Navarro JA, Sloan A, Michalsen JR, Stern AM, Cetron MS (2007). "Nonpharmaceutical interventions implemented by US cities during the 1918-1919 influenza pandemic”. JAMA. Aug 8;298(6):644-54.

Schwert, G. William. (1990). "Stock Returns and Real Activity: A Century of Evidence." Journal of Finance 45: 1237-1257.

Velde, Francois. (2020). "What Happened to the U.S. Economy During the 1918 Influenza Pandemic? A View Through High-Frequency Data." Working Paper Series WP 2020-11, Federal Reserve Bank of Chicago. 
Table 1. Summary Statistics

\begin{tabular}{lccccc}
\hline Variable & Obs. & Mean & Std. Dev. & Min & Max \\
\hline Equally Weighted Stock Market & 81 & 65.11 & 7.26 & 54 & 77.82 \\
Index & 81 & 581.37 & 907.38 & 46 & 4915 \\
Death Rate & 81 & 2.21 & 1.53 & 0 & 7 \\
War News & & & &
\end{tabular}

Source: Author's calculations

Table 2. Summary Statistics, NYSE Sectors

\begin{tabular}{lccccc}
\hline Sector & Obs. & Mean & Std. Dev. & Min & Max \\
\hline Automobile & 81 & 90.42 & 20.40 & 63.73 & 129.01 \\
Consumer Products & 81 & 102.18 & 14.11 & 82.09 & 128.11 \\
Light Manufacturing & 81 & 70.42 & 11.14 & 49.39 & 86.78 \\
Mining \& Oil & 81 & 33.84 & 2.56 & 28.30 & 39.11 \\
Other Manufacturing & 81 & 75.90 & 10.28 & 56.73 & 92.61 \\
Railroads & 81 & 55.50 & 3.24 & 47.66 & 62.80 \\
Steel & 81 & 54.70 & 6.53 & 42.88 & 66.32 \\
Trade \& Service & 81 & 111.19 & 10.69 & 91.70 & 129.03 \\
Utilities & 81 & 39.60 & 4.13 & 33.59 & 49.93 \\
\hline
\end{tabular}

Source: Author's calculations 
Table 3. Forecast Error Variance Decompositions for Nine NYSE Sectors

A. Death Rate

\begin{tabular}{cccccccccc}
\hline \multirow{2}{*}{ Weeks } & Automobile & $\begin{array}{c}\text { Consumer } \\
\text { Products }\end{array}$ & $\begin{array}{c}\text { Light } \\
\text { Manufacturing }\end{array}$ & $\begin{array}{c}\text { Mining \& } \\
\text { Oil }\end{array}$ & $\begin{array}{c}\text { Other } \\
\text { Manufacturing }\end{array}$ & Railroads & Steel & Trade \& & Utility \\
4 & $4.1 \%$ & $4.3 \%$ & $2.5 \%$ & $3.2 \%$ & $4.2 \%$ & $2.7 \%$ & $1.2 \%$ & $4.7 \%$ & $6.9 \%$ \\
8 & $15.3 \%$ & $21.2 \%$ & $11.5 \%$ & $17.7 \%$ & $17.2 \%$ & $5.7 \%$ & $7.6 \%$ & $18.9 \%$ & $22.3 \%$ \\
12 & $18.0 \%$ & $25.0 \%$ & $14.6 \%$ & $23.0 \%$ & $20.6 \%$ & $5.5 \%$ & $11.9 \%$ & $22.1 \%$ & $24.8 \%$ \\
16 & $17.7 \%$ & $23.3 \%$ & $13.9 \%$ & $23.0 \%$ & $19.1 \%$ & $5.7 \%$ & $13.4 \%$ & $21.4 \%$ & $24.1 \%$ \\
\hline
\end{tabular}

B. War News

\begin{tabular}{cccccccccc}
\hline Weeks & Automobile & $\begin{array}{c}\text { Consumer } \\
\text { Products }\end{array}$ & $\begin{array}{c}\text { Light } \\
\text { Manufacturing }\end{array}$ & $\begin{array}{c}\text { Mining \& } \\
\text { Oil }\end{array}$ & $\begin{array}{c}\text { Other } \\
\text { Manufacturing }\end{array}$ & Railroads & Steel & Trade \& & Utility \\
4 & $0.9 \%$ & $2.4 \%$ & $1.1 \%$ & $0.2 \%$ & $0.7 \%$ & $0.1 \%$ & $1.9 \%$ & $2.3 \%$ & $0.1 \%$ \\
8 & $1.8 \%$ & $4.8 \%$ & $2.5 \%$ & $0.9 \%$ & $1.1 \%$ & $0.1 \%$ & $2.5 \%$ & $4.8 \%$ & $0.3 \%$ \\
12 & $2.2 \%$ & $5.4 \%$ & $3.4 \%$ & $1.3 \%$ & $1.2 \%$ & $0.2 \%$ & $2.2 \%$ & $5.9 \%$ & $0.5 \%$ \\
16 & $2.5 \%$ & $5.5 \%$ & $3.7 \%$ & $1.5 \%$ & $1.2 \%$ & $0.3 \%$ & $2.0 \%$ & $6.3 \%$ & $0.5 \%$ \\
\hline
\end{tabular}

Source: Author's calculations 
Figure 1

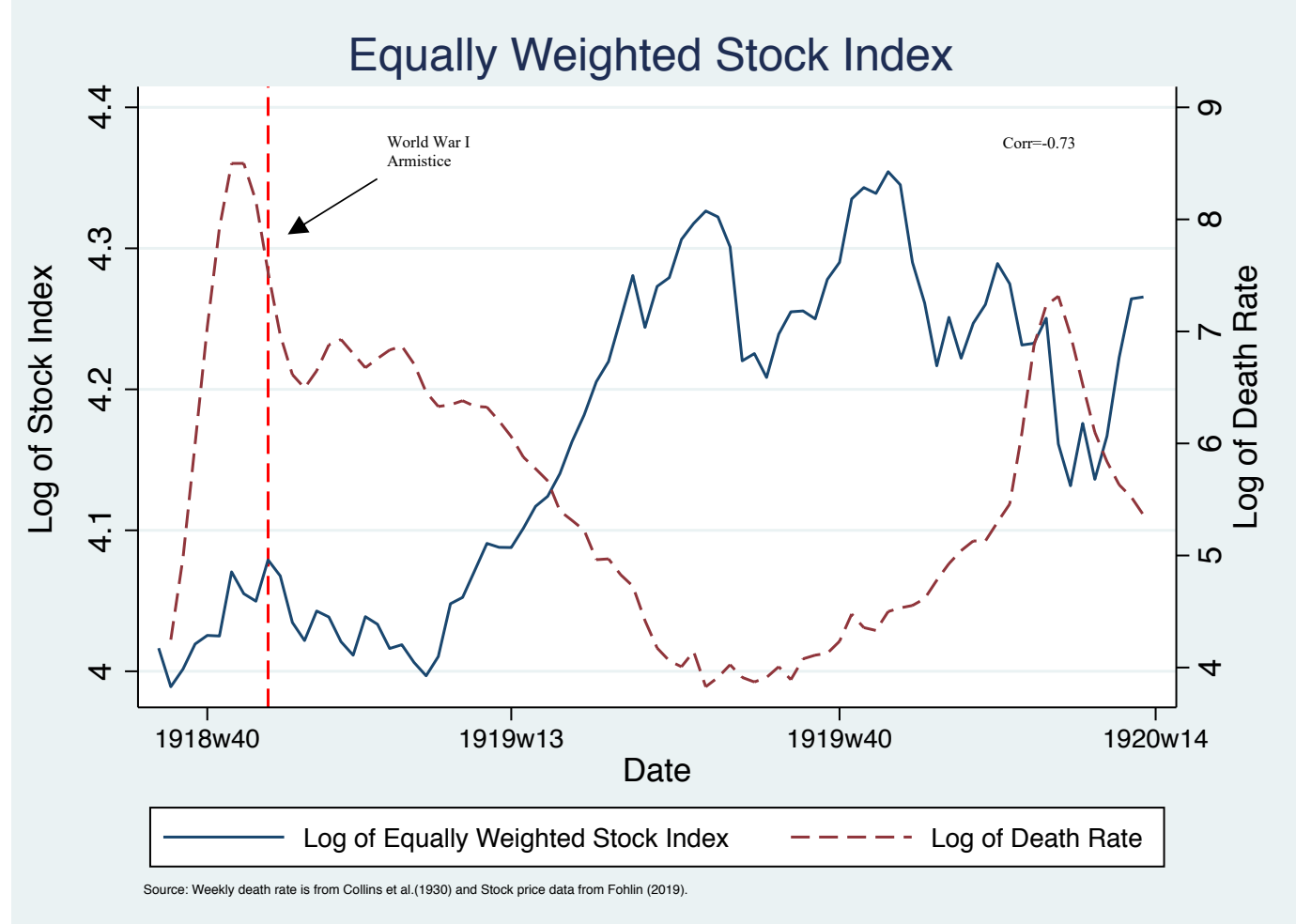


Figure 2. Impulse Response Functions for Aggregate Stock Market Index
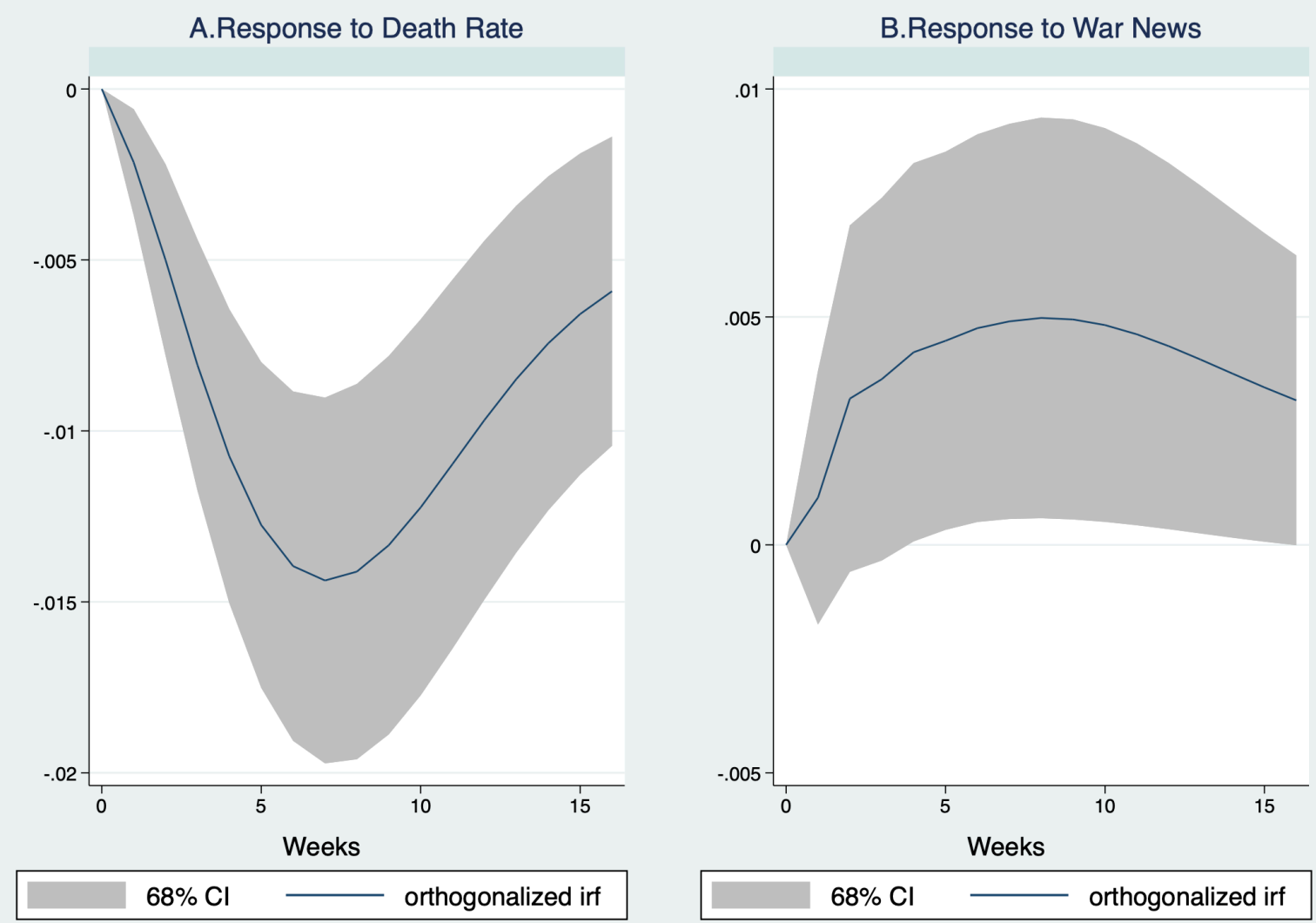
Figure 3A. Impulse responses of a given sector to a one-standard deviation shock to the log of death rate.

\section{Response to Death Rate}
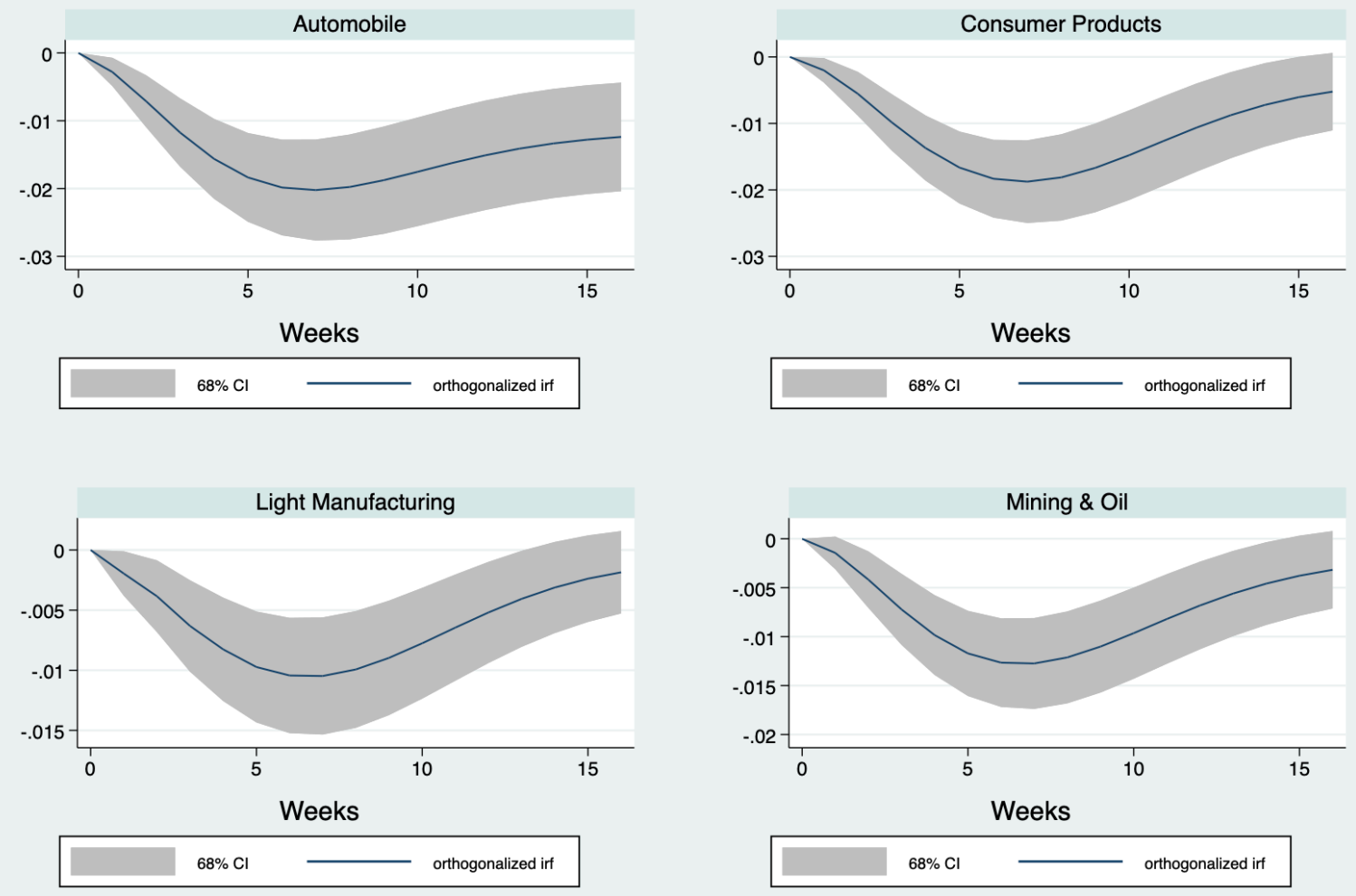
Figure 3B. Impulse responses of a given sector to a one-standard deviation shock to the log of death rate.

\section{Response to Death Rate}
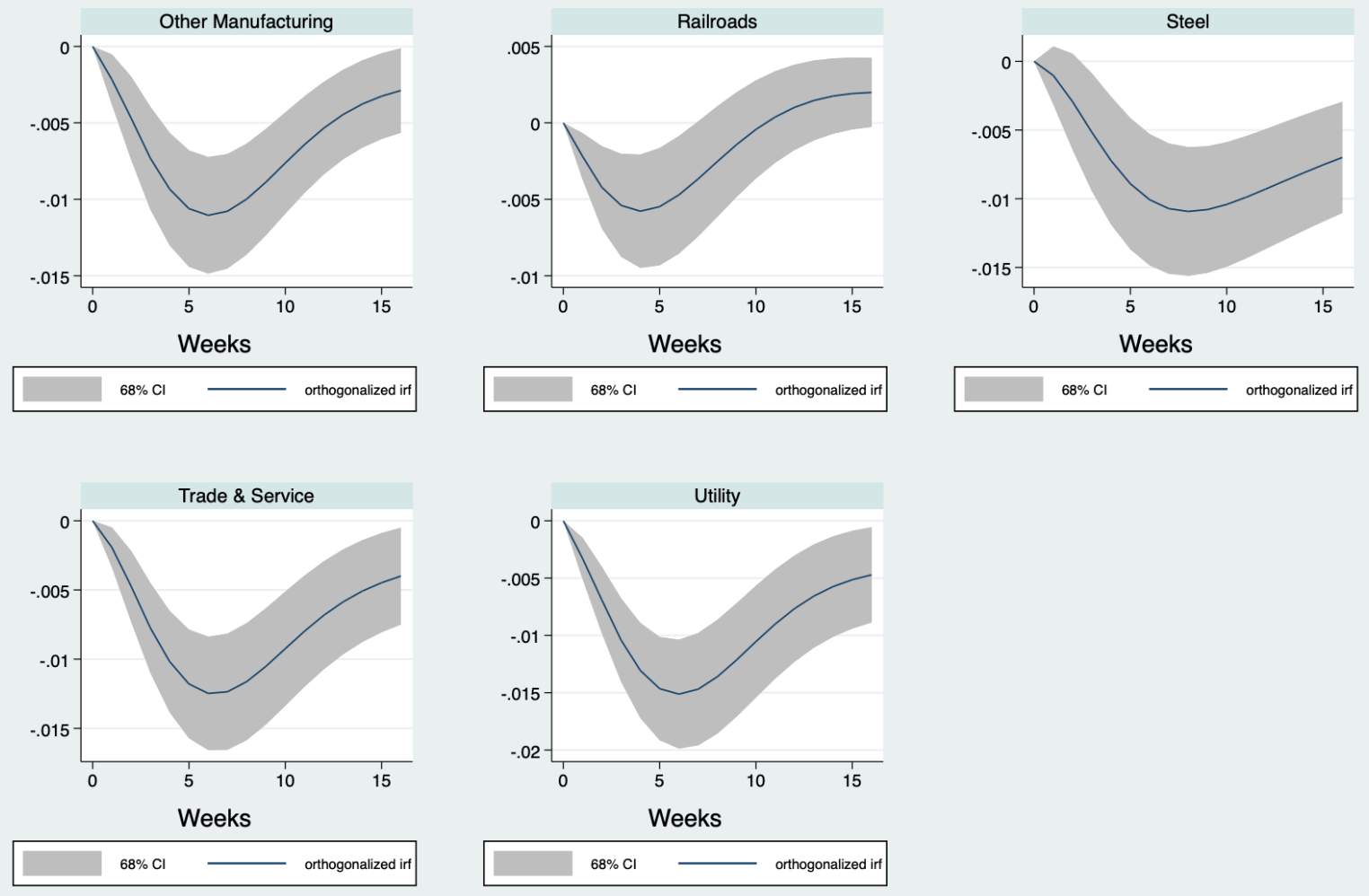
Figure 4A. Impulse responses of a given sector to a one-standard deviation shock to war news.

\section{Response to War News}
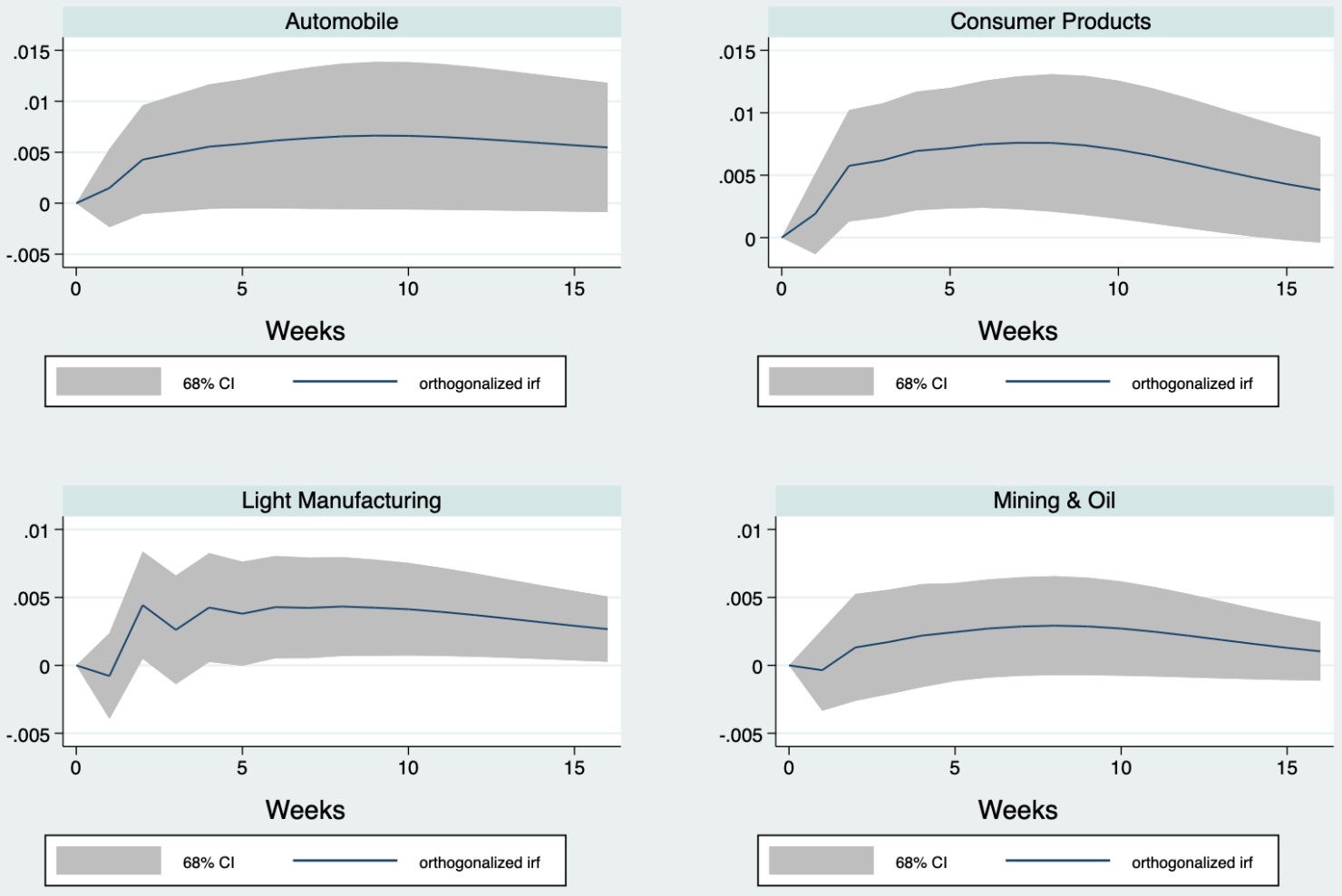
Figure 4B. Impulse responses of a given sector to a one-standard deviation shock to war news.

\section{Response to War News}
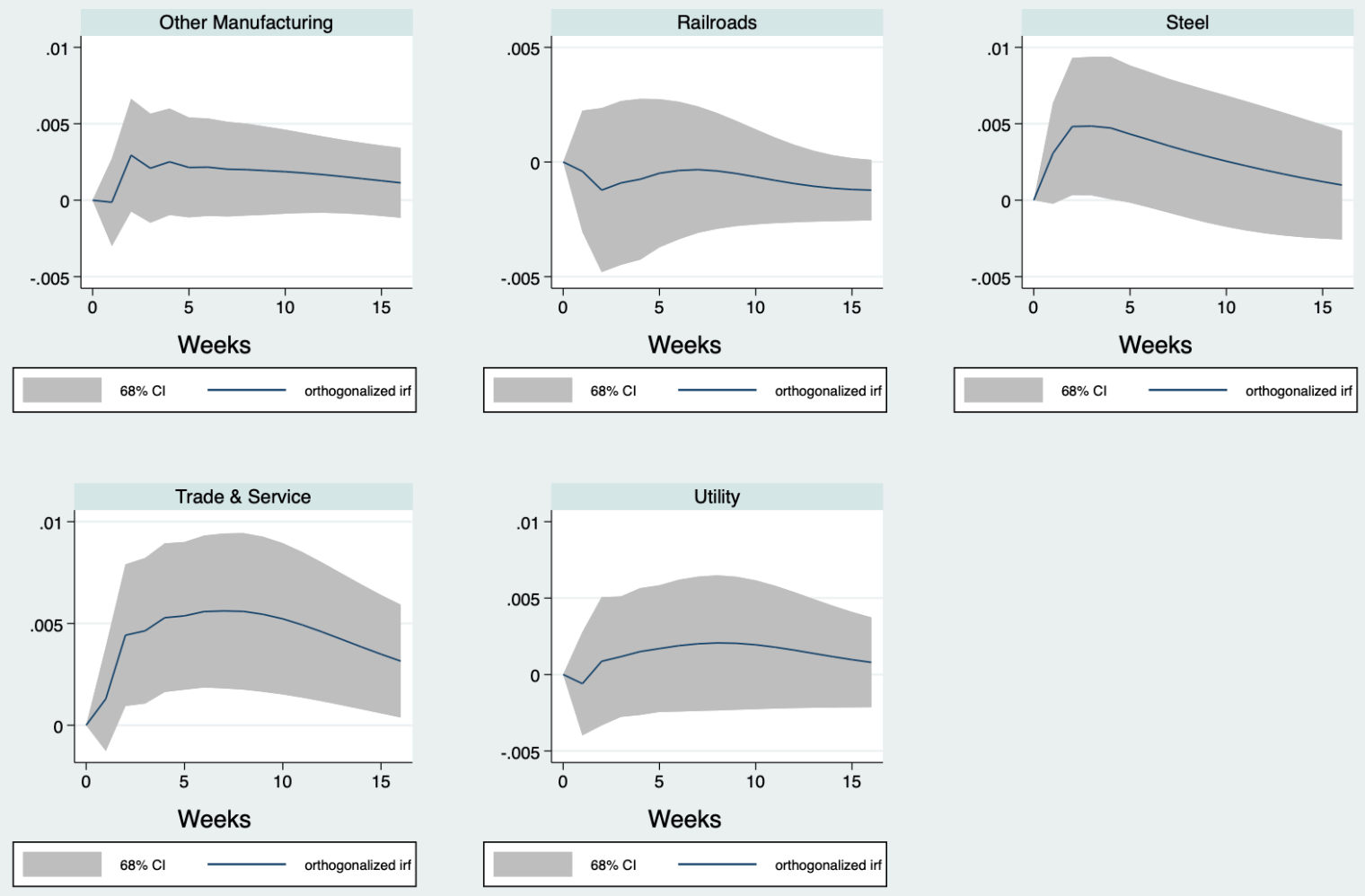


\section{Appendix}

\section{Additional Figures}
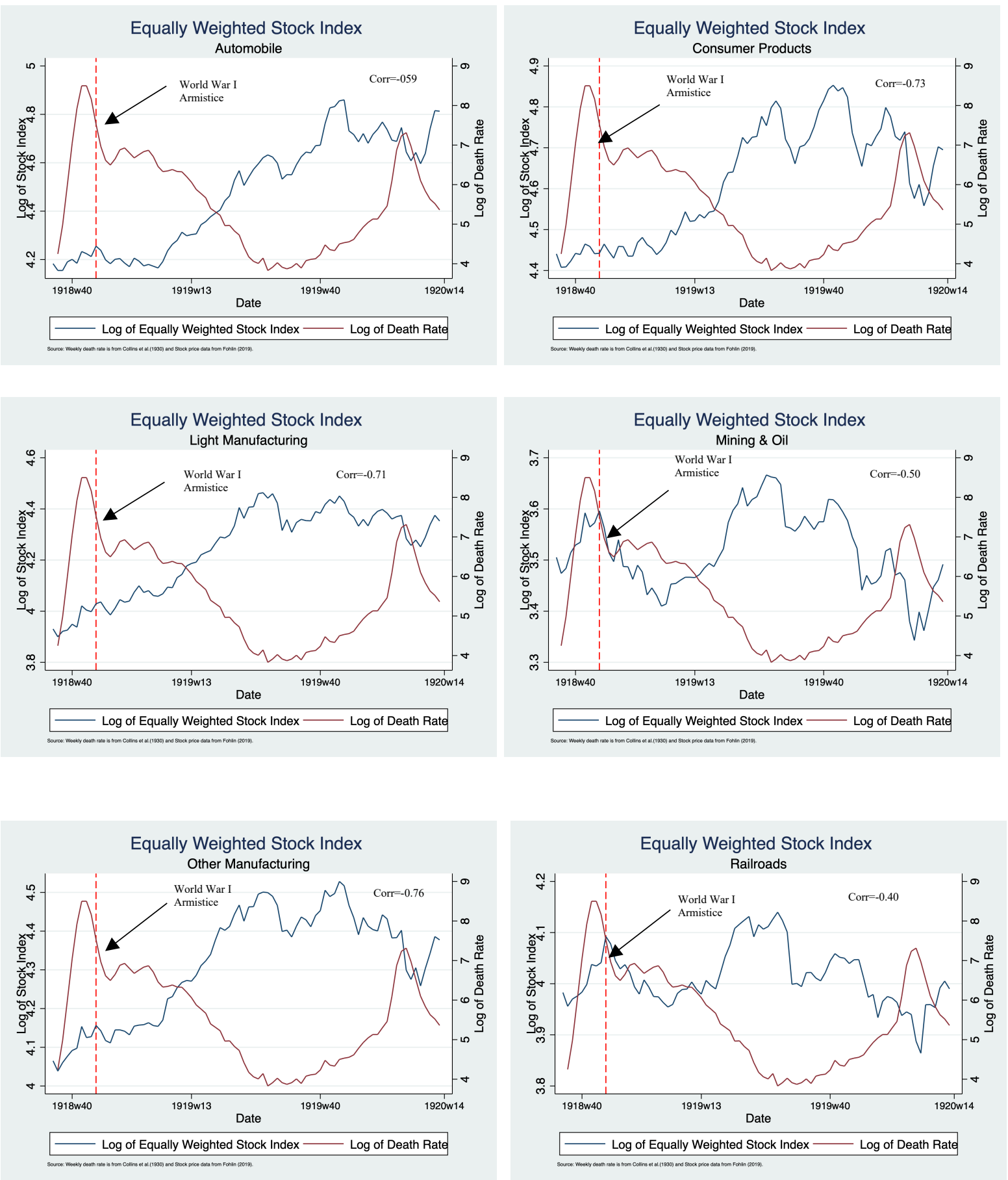

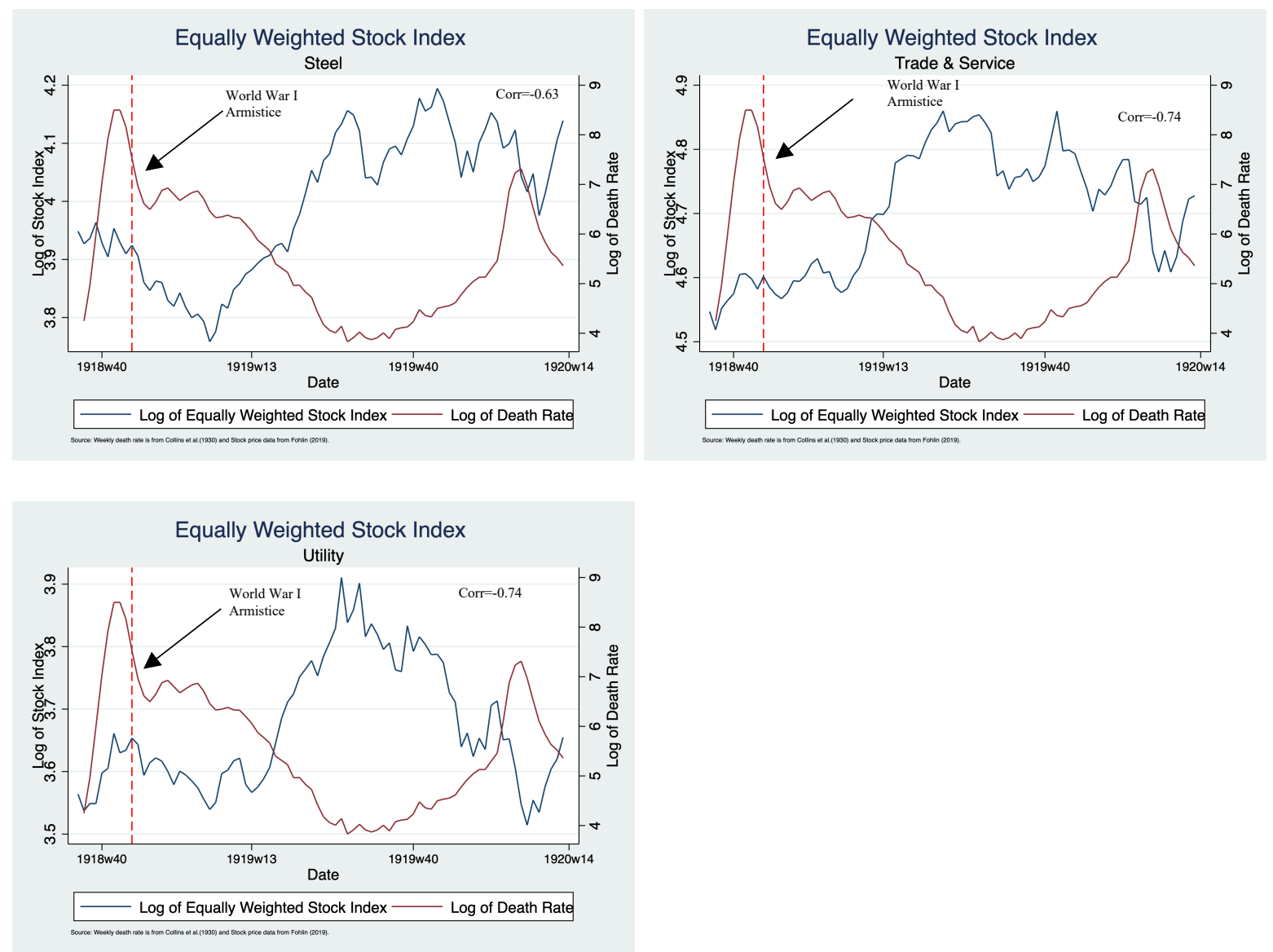